\title{
By neglecting George Perkins Marsh, we only have Paulo Freire's utopia
}

\author{
Lima Nakaoshi $\mathrm{I}^{1}$, Rojas Vasques $\mathrm{F}^{2}$ and Fortunato $\mathrm{I}^{3 *}$ \\ ${ }^{1}$ Licenciatura em Física, Federal Institute of São Paulo, Brazil \\ ${ }^{2}$ Faculdade de Letras da Universidade do Porto, Portugal \\ ${ }^{3}$ Coordenadoria de Formação Pedagógica, Federal Institute of São Paulo, Brazil
}

*Corresponding author: Ivan Fortunato, Full professor at the Federal Institute of São Paulo, Itapetininga, São Paulo, Brazil, Email: ivanfrt@yahoo.com.br

\author{
Perspective \\ Volume 4 Issue 2 \\ Received Date: April 23, 2021
}

Published Date: May 13, 2021

DOI: $10.23880 / a b c a-16000183$

\section{Abstract}

This paper seeks to demonstrate that the environmental issues were pointed out by George Perkins Marsh at least one hundred years before it become a part of the global agenda in the 1970s. As per our research we can we can clearly state that the negligence given to his book "Man and Nature", in which he has proven that aggression to nature meant aggression to human life, became responsible for the serious environmental problems that we have today. If a return in time is unlikely to prevent industrial capitalism from following its rite of destruction-production-oppression-consumption all we have is the hope that all of this can be mitigated in some way. We bet on environmental education, mainly mediated by hope and utopia very well outlined by the patron of Brazilian education, Paulo Freire. This article is an essay in which we weave together neglect with hope.

Keywords: Environmental Education; Man and Nature; Oppressor-Oppressed

\section{Introduction}

This paper discusses environmental issues in the light of a utopia built through popular, critical, libertarian and transformative education, inspired by the ideals of the patron of Brazilian education, Freire P, et al. [1]. When starting an analysis on the development of human interference in nature and its consequences, it is necessary to be concerned about the environmental crisis. Such interference becomes more aggressive with technological development, which introduces a greater need for the production of inputs, encouraging the unrestrained extraction of raw materials. As Quintana A, et al. [2]: "(...) the growing search for profit means that the production of goods must always be high and progressive, which generates a plunder of natural resources on a large scale". This is driven by the increase in population demand more and more consumerist which, following the logic of the market, it attributes the sign "profit" to nature Nakaoshi IL, et al. [3]. In a general look at our globalized society, we observe that, as new technologies emerge, they become essential for the world, eventually bringing a new standard of living that requires greater extraction, production and negative interference with nature.

So, where is the necessary environmental concern? Would it be something isolated, separate from the productive world, reserved for a small portion of the population, who are referred to as environmentalists? Yet, would this concern be something romanticized, which puts nature at the center of the universe, just like the Gaia hypothesis Lovelock J, et al. [4], for example? We believe that none of this proceeds. 
The environmental concern that we believe is based on the dialogical relationship between human beings and nature, which promotes the understanding of a complex and integral environment, which includes people and all their cultural production and the entire natural world Fortunato I, et al. [5]. Therefore, all aggression against nature and all aggression against people (including the oppression of the system), becomes an environmental aggression to which we are all subject to its negative effects.

Thus, tracing an analytical bias, we return to the 19th century, more specifically in 1864, in a historical period in which the Industrial Revolution caused the beginning of blunt aggression against nature and the exploitation of human labor. The promotion of a new type of social relations was backed by the new technological artifacts, which were used as weapons against nature, since they increased the capacity to extract raw material and to produce good and ever since the beginning of large-scale industrial production, stated Quintana A, et al. [2]: “(..) significant environmental impacts were already noticeable as important social impacts becoming widespread, including land degradation by capitalist agriculture and the exploitation of the labor force".

In this context, the technologies that enabled large-scale production were called "human ingenuity" in the book "Man and Nature" Marsh GP, et al. [6], written by the northAmerican George Perkins Marsh. This author was the pioneer to contribute to the understanding of the environmental impacts that could occur due to the increase of human interference in nature Almeida A, et al. [7].

We believe that Marsh's work We believe that Marsh's work has been neglected for decades, as the environmental issues only started to be part of the agenda of global concerns in the 1970s, becoming effective at the famous United Nations conference, held in Rio de Janeiro (Brazil) in 1992 the event became known as Rio-92 or Eco-92. Well, as it is unlikely a return in time to make Marsh's warnings heard and, with that, turning industrial capitalism unable to follow its rite of destruction-production-oppression-consumption, all we have is hope that all of this can be mitigated in some way. We bet on environmental education, mediated mainly by the hope and the utopia of Freire's education. That's what our discussion is about in this writing.

\section{Discussion}

More than a century and a half after the publication of the book "Man and Nature", it is well known that Marsh GP, et al. [6] was one of the first (if not the first) to warn the world about several environmental catastrophes already materialized, which brought negative consequences to human life itself. To get a sense of the importance of Marsh for the construction of the environmentalist ideal, we must point out his predictions, that is, his alarmist view on then possible negative consequences of human interference in nature observed by him in the midst of his social activities, presented in 1864 in "Man and Nature".

This a important passage from the book "Man and Nature" by Marsh GP, et al. [6]; Almeida A, et al. [7]: "In addition to the larger creatures of land and sea, quadrupeds, reptiles, birds, amphibians, crustaceans, fish, insects and worms, there are countless other forms of life". This annotation is concluded with the following note: "The land, the water, the ducts and fluid of plant and animal life, the air we breathe, are populated by tiny organisms that perform the most important functions in both the animate and inanimate realms of nature".

Observing this passage, we can conclude that Marsh understood the importance of all living organisms for the animate and inanimate functions of nature. This becomes clear when, while playing the role of Fisheries Commissioner, Marsh produced reports that demonstrate his concern about the decline of certain species of fish Almeida A, et al. [7]. Tracing a contextualization to the present day, we observe the rise of the fishing industry, which, with the advent of technology at the turn of the century, allows more aggressive ways to extract the raw material: the fish. One example is trawling, which is "the most severe and extensive disturbance on the seabed in the world" [8]. According to Pusceddu A, et al. [9] when making a comparison between areas that are and are not attacked by this type of fishing, it is noticed that there is a loss of at least $50 \%$ of marine biodiversity by the industrial sweep of the ocean floor.

Assessments of offshore fish populations indicate that fishing has led to extraordinary reductions in the abundance of many species in the open sea. Who benefits from this? Fish catches are reported by states, but companies capture and profit from this industrial market in the global ocean. Carmine G, et al. [10], combines satellite data with other public databases, and shows that 1,120 corporate actors owned 2,482 deep-sea fishing vessels in 2018 .

According to Ticker D, et al. [11] the fishing industry is in crisis. As a consequence of unbridled extraction, twice as much effort is currently required to catch the same amount of fish when compared to the 1950s. To maintain this system, cases of labor abuse and even modern slavery are found, which exploits vulnerable workers by cheap labor.

Regarding fires that occurred in the Brazilian tropical forests in 2020, with the purpose of obtaining land for cattle breeding and soy plantations to feed these animals, it is notorious to highlight the industrial sector as responsible for the destruction of 3,461 million hectares of native forest 
in the Pantanal, according to the National Pantanal Research Institute Nakaoshi IL, et al. [2]. Going deeper into the impact on the Brazilian reality, we can declare that the livestock industry is the protagonist of these fires, since a large part of the burnt areas end up becoming pastures and plantations that in the great majority end up having the purpose of feeding and / or rearing of slaughter animals Nakaoshi IL, et al. [2].

We can also analyze a section of "Man and Nature" on the impacts of rural and industrial enterprises: “(...) rural and industrial developments tend to produce major changes in hydrometry, thermometry, and the chemical and electrical condition of the atmosphere, although we are not able to measure the strength of the different elements of disturbance" Marsh GP, et al. [6].

To end our contextualization of the importance of Marsh, which aims to reveal that the author was neglected, we cannot fail to mention his warnings about temperature variation and possible changes in the geography and life of species that deforestation could bring: "It seems quite certain that no cultivated land is as efficient in moderating climatic extremes, or in conserving geographic surface and structure, as the soil that nature itself has created" Marsh GP, et al. [6].

However, "Man and Nature" extrapolates these relations presented above and reiterates the analysis of the imbalance in biodiversity caused by excessive hunting and the generation of waste, in addition to warning about the extinction of future species of nature, etc.. We then realize that, by bringing Marsh GP, et al. [6], to contemporary times, his warnings became reality. The author wrote "Man and Nature" with the proposal of preventing the population from the negative consequences of human interference in nature so that they do not carry them out. Yet, after a century and a half after the book was published, the negatives consequences become more and more concrete. Taking into account the historical context in which the book was written, we ask ourselves: if Marsh had not been historically neglected, would we be living in a better world?.

Unfortunately, as we have already outlined, going back in time and valuing "Man and Nature", preventing industrial capitalism from following its rite of destruction-productionoperation-consumption, it is unlikely. Therefore, there is hope that all this can be mitigated. We go with Paulo Freire, who traces a path of hope towards criticality-liberty-equalityutopia, using emancipatory, critical and liberating Education as a tool, which can be used in several areas, including Environmental Education Dickmann I, et al. [12].

When introducing the Freirian perspective in the historical debate of Marsh GP, et al. [6], it is important to update the dialetical view between human beings and nature that the author raised; it is necessary to articulate an integrated vision of human-nature, a Freirian vision Dickmann I, et al. [13], including socio-environmental problems into the equation. By highlighting the importance of establishing criticality with the presentation of the nuances of environmental issues, an oppressor-oppressed relationship is traced Freire $\mathrm{P}$, et al. [1]. This relationship becomes clear when we analyze where and on whom environmental disasters fall most heavily.

For this reason, we return to Freire P, etal. [1] as a proposal to understand today's society, with the objective of building a new perspective on critical and liberating environmental education, in an attempt to prevent further environmental degradation (and its fallouts) from occurring. It is a question of tracing a path towards utopia, that is, towards a less unequal and more ethical society. Perhaps, thus, hope can motivate a constantly evolving reality, understanding the mistakes of the past and their relevance for the present day in order to build an environmentally utopian future.

In a previous paper Nakaoshi IL, et al. [2], we present the way in which the consequences of environmental degradation decline more violently in underdeveloped countries and in more vulnerable social classes. Going further, we present the Freirian perspective analyzed by Dickmann I, et al. [13] on the human-nature relationship that, according to the authors, should be revised, because, in the Freirian sense, man and nature do not have a dualistic relationship, but internalized. In this sense, all oppression of nature is directly related to human oppression, and vice versa, becoming essentially an environmental oppression to which we are all refractory.

Based on this dialectical relationship, the materialization of environmental catastrophes dissects the degree of this oppression with the awareness of the existence of an oppressed class, which clashes with the protagonists of the oppression of nature, we observe an oppressiveoppressed relationship: the top of the capitalist-industrial, or political-corporatist pyramid. Based on Freire $\mathrm{P}$, et al. [1] wanderings, it is important to present an ideation of Environmental Education, through which the complexities of environmentalism are presented, with the objective of developing autonomy, critical sense, empathy, seeking ways to release the bonds of the cycle of oppression. After all, as Freire P, et al. [1] pointed out, the oppressed can become oppressors.

The importance of Freirian education begins when we understand the meaning of breaking the cycle of oppression. According to his "Pedagogy of the Oppressed" (1987), the logic of oppression is structured to favor a ruling class, which ends up bringing the underprivileged part of the population 
to a lack of awareness of their fundamental rights, and, consequently, non-awareness of their role as oppressed. In this perspective, class consciousness becomes necessary for the liberation of the oppressed from their role imposed by the oppressive system. When applying the logic of oppression in the educational context, we produce a cycle that ends up turning the students (oppressed) into future oppressors, since the Freirian logic of criticality-freedom-equality-utopia is not established, perpetuating this cruel system.

When placing students on the level of agents of change in their own lived realities, it is essential to prioritize liberatingautonomous education as a way of transforming the society in which they are inserted. It is a political-critical education, which presents the complexities of the neoliberal, industrial and capitalist system, driven by the logic of non-egalitarian oppression.

It is essential to relate Freirian educational ideas to the nuances of critical environmental education, which runs counter to a systematic logic of oppression to nature. As it was dissected in the arguments, this analysis is important so that there is a greater perception of the need to fight against environmental oppression, which mainly impacts the less favored social classes. For this, we must cling to hope, to continue our journey towards the application of the teachings of Freire P, et al. [1], because without hope, there is no utopia. So, to end (momentarily) this discussion we leave his own words resonating, in a free translation into English:

We would be idealists if, by dichotomizing the action from reflection, we could either understand or state that the simple reflection on the oppressive reality, which would lead men to discover their state of objects, already, meant they were subjects. There is no doubt, however, that, if this recognition does not yet mean that they are subjects, concretely, "it means, said a student of ours, to be subjects in hope". And this hope leads them to search for its concreteness Freire P, et al. [1].

\section{Conclusion}

We begin the arguments presented here by recovering the importance of Marsh GP, et al. [6] for environmentalism, since his manifesto was probably the first to present the dangers of excessive human interference in nature. In declaring Marsh as essential, we understand that his predicates have been neglected by mankind because, after a century and a half of the publication of "Man and Nature", we realize that his environmental warnings have materialized. And it has been intensifying, aggravating the environmental crisis.

From a Freirian perspective, we believe it is possible to relate Marsh's historical importance with the current social reality, attributing in the equation the socio-environmental character and the integrated view of human-nature, as well as an analysis of the factors that dissect the oppressoroppressed relationship in the complexities of today's society.

With that, we conclude that the neglect of Marsh's concern was something overbearing on the part of a society that believed (and still believes) in a healthy relationship between exacerbated environmental degradation and human progress. This arrogance contributed to an environmental degradation, bringing several negative consequences for life although they were long warned in Marsh's "Man and Nature".

It is no longer enough to understand the damaging impact of this neglect. It is necessary to migrate towards a democratic, environmental and critical human evolution, which understands the environmental complexity through the dialog between the cultural and the natural world. If education can transform the world, may it be for the better. May it be through hope for a more ethical and less unequal world, which is the greatest legacy left by Freire P, et al. [1].

\section{References}

1. Freire P (1987) Pedagogia do Oprimido Paz e T 17th (Edn.), Erra, Rio de Janeiro.

2. Quintana A, Hacon V (2011) Development of capitalism and an environmental crisis. Social em Questão, Rio de Janeiro, pp: 427-444.

3. Nakaoshi IL, Vasques FR, Fortunato I (2021) Paulo Freire is his legacy for a utopia in environmental education. In: Rodriguez ME, et al. (Eds.), The walker of Utopia. Anglo Spanish University Institute, Durango.

4. Lovelock J (2001) To Vingança de Gaia. Rio de Janeiro: Intrinseca Editor.

5. Fortunato I (2014) Meio-Ambiente: or challenge of education versus paradoxical environmental Etd: Digital Thematic Education 16: 386.

6. Marsh GP (1864) Man and Nature; or, physical geography as modifie, London.

7. Almeida A, Joana F, Vasconcelos C (2014) Revisiting "Man and Nature" by George Perkins Marsh, or pioneer of environmentalism. História das Ciências para o Ensino, Coimbra, pp: 86-104.

8. Sea Web (2008) Bottom Trawling Impacts on Ocean, Clearly Visible From Space. Science Daily. 
9. Pusceddu A, Bianchelli S, Martin J, Puig P, Palanques A, et al. (2014) Proceedings of the Nation Academy of Science 111(4).

10. Carmine G, Mayorga J, Nathan MA, Österblom H, Sala E, et al. (2020) Who is the high seas fishing industry? Elsevier Inc, pp: 730-738.

11. Ticker D, Meeuwig J, Bryant K, David F, Zeller D (2018) Modern Slavery and the Race to Fish. Nat Commun 9.
12. Dickmann I (2017) Educação Ambiental Freiriana: Assumptions and method. Journal of Human Sciences Educação, Frederico Westphalen 18(30): 117-135.

13. Dickmann I, Carneiro SM (2012) Paulo Freire and Environmental Education: contributions from the work Pedagogia da Autonomia. Journal of Public Education 21(45): 87-102. 